\title{
GRANTS SUPPORTING INNOVATION INTERMEDIARY ORGANIZATIONS
}

\section{AZ INNOVÁCIÓS KÖZVETÍTŐ SZERVEZETEK TEVÉKENYSÉGÉT TÁMOGATÓ PÁLYÁZATI FORRÁSOK}

\author{
Éva GAJZÁGÓa - Gergő GAJZÁGó ${ }^{\mathrm{b}}$
}

\author{
a assistant professor and TTO leader, Edutus College, Studium square 1, H-2800 Tatabánya, +36-34-520- \\ 411,gajzago.eva@edutus.hu \\ ${ }^{b} \mathrm{PhD}$ student, Széchenyi István University, Doctoral School of Regional- and Economic Sciences, \\ Egyetem square 1., H-9026 Győr, gajzago.gergo@sze.hu
}

Cite this article: Gajzágó, É., Gajzágó, G. (2016). Grants Supporting Innovation Intermediary Organizations. Deturope, 8, 2: 35-47

\begin{abstract}
Resources gained from tenders have been gradually increasing since Hungary joined the European Union. The overall objectives of projects financed by EU tenders need to be closely connected to the goals - like increasing the innovation potential - as it is emphasized by European strategies.

Innovation intermediary organizations play a significant role in the innovation process. According to the literature, innovation intermediary organization received high amount of development support between 1991 and 1994. During the years before Hungary joined the EU, the national innovation system was supported by several public and pre-accession funds. Resources available for innovation intermediaries in the decade before and after 2004 are not closely examined in literature. The present article tries to supplement this incompletion with the description of the resources between 2004 and 2012.

The main goal of the article is to introduce with what kind of financial assets Hungarian innovation intermediary organizations were supported. The article also wishes to highlight the related financial problems of the organizations. In the article we introduce financial support - and its spatial distribution available and gained by innovation intermediary organizations. In the article, after summarizing the related literature, we introduce our research and its main results. Based on the results of our national level research examining innovation intermediaries, we compare the distribution of these resources to the number and management effectiveness of these organizations.
\end{abstract}

Keywords: innovation intermediary organizations, application grant

\begin{abstract}
Absztrakt
Magyarország Európai Uniós csatlakozása óta fokozatosan növekednek a pályázati úton rendelkezésre álló források. A pályázatokból finanszírozott projektek átfogó céljainak szorosan kell kapcsolódniuk az Unió által is hangsúlyozott célokhoz, például az innovációs potenciál fejlesztéséhez.

$\mathrm{Az}$ innovációs folyamatban jelentős szerepük van az innovációs közvetítő szervezeteknek. A szakirodalom szerint az innovációban résztvevő szervezetek kiugróan magas fejlesztési forrásokhoz jutottak 1991 és 1994 között. Magyarország EU-s csatlakozása előtti években több állami forrás, illetve előcsatlakozási alapok támogatták a hazai innovációs rendszert. A 2004 utáni időszakban lehívható, az innovációban résztvevő, közremüködő szervezetekkel kapcsolatos forrásokról azonban nem találunk a szakirodalomban átfogó elemzést. A jelen cikk, illetve előadás ezt a hiányosságot kívánja pótolni, a 2004 és 2012-es időszak támogatásainak bemutatásával.

A cikk fö célja, hogy bemutassa milyen finanszírozási eszközök támogatták a magyar innovációs közvetítő szervezeteket. A cikk arra is rávilágít, hogy milyen finanszírozási problémáik voltak a szervezeteknek. A cikkben, a szakirodalom összefoglalása után bemutatjuk a kutatásunkat, illetve annak
\end{abstract}


főbb eredményeit. Az országos szintű, az innovációs közvetítő szervezeteket vizsgáló kutatásunk eredményeire alapozva pedig összevetjük a források elosztását a szervezetek számával, illetve müködési hatékonyságával.

Kulcsszavak: innovációs közvetítỏ szervezetek, pályázati források

\section{INTRODUCTION}

The role of innovation became more and more important in the last decades due to the globalization process. The Europe 2020 strategy of the EU is also focuses on the development of innovation potential and innovation effectiveness. Besides, innovation is also emphasized in national level as it has a significant role in economic development and in managing the problems following an economic crisis. A key element of the development of national economies is the advancement of economic sectors' innovation potential, which can be promoted through the establishment and development of innovation systems by the national governments (Flanagana et al., 2011, and Arocena-Sutz, 2002,). Supporting the transfer of inventions from higher educational institutes to business and industrial sectors - as knowledge transfer - is also an important task (Nagaoka et al., 2009).

In national economies the role of innovation intermediary organizations has also increased as intermediaries through their services and activities are focusing on the cooperation and the establishment of trust-based partnerships between knowledge creators and knowledge users such as the establishment of a relationship between companies and researchers.

Several articles - like Freeman (1987,1995), Lundvall (1992, 2002), Inzelt (1998), Nagaoka et al. (2009), Nelson (1993), Fagerberg (1994, 2005), Landes (1998), Arocena Sutz (2002), Afuah (2003), Trott (2004), Döry (2005), Castellacci (2008), Mokyr (2002), define and describe the national innovation system (NIS). Freeman (1987) defines the NIS as the netweor of public and private institutes having a leading role in the innovation process. Lundvall (2002) emphasizes that one of the key elements of the NIS is the public financing of innovation as it is closely connected to the knowledge creation. Nagaoka et al. (2009) lists the development assets of the innovation system like the systematic and coherent public support and the increasing the share of these support in the public budget.

Organizations which have a role of an intermediary in the innovation process are significant in the development of innovation potential. Many articles emphasize that supporting the establishment and management of these intermediaries is an important role of the governments. Participants and intermediaries of the NIS are also analysed by several literature - as Barta (2002), Buzás (2007.), Csizmadia - Grosz (2011), Filippetti - Archibugia 
(2011), Guana - Chen (2012), Howlet (2011), Jain - Triandis - Weick (2010), Lengyel Leydesdorff (2008), Lux (2013), Molnár (2004), Stamm (2003), Szépvölgyi (2006), Vekinis (2007, 2014). Filippetti and Archibugia (Filippetti - Archibugia, 2011) describe that the innovation process of companies is intensely influenced by those national systems and processes which can influence cooperation, patenting, financial process or higher education regarding to innovation. These processes of the national innovation systems clearly define the services of intermediaries too. Guana and Chen (Guana - Chen 2012) state that innovation policies should emphasize the cooperation of actors (institutes) in the innovation process and the establishment of innovative atmosphere. Lux (2013) and Csizmadia - Grosz (2011) also emphasize the importance of the supporting organizations, specific regional characteristics and cooperation. The support for establishing partnerships is a basic service of innovation intermediaries. Flanagana et al. (Flanagana et al., 2011) highlights, that innovation can be supported on national level with several assets by the national governments. These supports are complex and contain more specific instruments and possibilities. Molnár (2004) introduces the main strategic assets of the establishment of the NIS and emphasizes the importance of the economic and institutional supporting system.

In this recent article, based on the above mentioned literature, we analyse the support for Hungarian innovation intermediary organizations. We describe with which-mainly financial - assets were available for these institutions between 2006 and 2013 from national and European Union resources.

Hungarian tenders and EU grants are described in several articles. For instance, Lóránd (Lóránd, 2008) analyses the results of regional and local development programmes. Mezei (Mezei, 2004) explaining the financing system of Western-Transdanubian Region, wrote that the Hungarian supporting system is not stable in time and its regular changes result the short term reflectiveness and unsteadiness of the stakeholders (actors). Perger (Perger, 2010) in her article also introduces the system of Hungarian national grants through their utilization and effectiveness. She emphasizes that utilization of Hungarian resources form grants is not effective. However the usage of grant financing on program and project level is efficient, but this result does not influence significantly macro-economic indices.

Resources directly for Hungarian innovation services and for intermediaries are analysed by Döry (Döry, 1996). The author explains that in several Hungarian counties, like in Pest and Borsod-Abauj-Zemplen county, between 1991 and 1994 organizations participating in the 
innovation process received saliently high development funds. The high number of organizations in these counties can be explained by this tendency. Dániel (Dániel-Molnár, 2013) gives more details according to these resources in his article, examining the development funds focusing on the increase of innovation capacity of SMEs.

Innovation intermediaries and their services were examined by Grosz-CsizmadiaSzépvölgyi in their articles (e.g. Grosz-Csizmadia-Szépvölgyi, 2004) on regional level. They state that the most insistent problem of these organizations is that their financing is unpredictable and the fund they can involve are on a very low level or are totally absent. Besides, these factors acutely decrease their effectiveness and sometimes result in the termination of the organizations.

Accordingly, examining the grants and tenders for innovation, intermediary organizations and the received funds are important due to the followings:

- It underpins the above mentioned statement i.e. the support for managing these innovation organizations is substantial for the development of the innovation system and innovation potential.

- It provides information about the continuousness of financing these organizations. Continuous financing is necessary for a stable work.

- Examining the goals of the support and the supported projects, we can receive information about the management and the services of innovation intermediaries.

\section{THE BASICS OF THE RESEARCH}

The research described in this article was elaborated as a part of a larger survey of the innovation intermediary organizations. The basic research aimed to define the group of intermediaries and examine and describe their work, management and services, thus their effectiveness. The empirical research focused on a target group of organizations participating in the Hungarian innovation system as intermediaries - offering innovation counselling, knowledge transfer and support for the actors of the innovation process - aiming to develop and create the 'object' of innovation (the innovative product) according to consumer needs and to transfer it to the costumers. Besides, the sample of the research also contained those intermediary organizations which operate inside (as a part of) or near the higher education institutes and play a significant role in technology and knowledge transfer.

The research - between 2010 and 2013 - examined the intermediaries of the innovation process by a national levels survey. This research contained three types of surveys: 
- an analysis of statistical data - e.g. grants for the intermediaries,

- a secondary research about the publicity of the organizations (examining e.g. webpages, leaflets) and

- a questionnaire survey targeting innovation intermediary organizations.

The national level primer research - using questionnaires - aimed to examine the management effectiveness of the organizations. In the research 163 intermediary organizations were addressed and 129 answered the questionnaire. The survey contained detailed questions about the offered services, financial support, organizational types and target groups of the intermediaries.

The analysis of the grants (through the examination of seconder statistical resources) was examined according to the data available on the Hungarian official webpage of grants (palyazat.gov.hu) and the webpage of the National Research, Development and Innovation Office (NRDIO).

During the analysis of supports we only focused on those grants which were attainable only for innovation intermediary organizations for their establishments, services and management. The research examined three main programs which supported these organizations and activities:

- the Baross Gábor Program,

- the Operative Programs of the New Hungarian Development Plan (Új Magyarország Fejlesztési Terv, hereinafter referred to as ÚMFT) and

- the Operative Programs of the New Széchenyi Plan (Új Széchenyi Terv, hereinafter referred to as ÚSZT)

Attainable grants were also examined according to the subject of the call and by regional level. Besides we analysed the total sum of support (per calls) per region thus the regional distribution of the grants. On the other hand, the analysis of the sum of the grants per organizations served as a basis for the research about the services and effectiveness of intermediaries.

\section{RESEARCH RESULTS}

First we introduce the research results of grants of the above mentioned Baross Gábor Program. This program was the first which supported the establishment of innovation intermediary organizations and most of the technology transfer offices (TTOs) were funded by this Program and developed their services. 
The Baross Gábor Program offered different support in the regions - the grant differed by the amount of aid and by supported activities too. In some regions specific subjects were also supported by the program- like the development of spin-off services in the WesternTransdanubian Region or the elaboration of innovation surveys in the Northern-Hungarian Region or the development of property rights and pattern services in the CentralTransdanubian Region in 2008. (The title and code of the examined grants are in the Notes)

We should emphasize that all the available grants - as the Baross Program and also the EU grants - can only be acquired through applications from calls which support projects of specific subjects and activities. Besides, according to the Baross Gábor Program, we need to mention that not all the applicants who gained support can be defined as an innovation intermediary organization.

The number of supported organization was the highest in the Central Transdanubean Region and the lowest in The Southern Great Plain Region. The high number of the supported organizations in the Central-Transdanubean Region relates to the high financing framework in the region - the total sum of the support (see Table 1.) and also the number of calls was the highest here. Most of the supported organizations in this region were forprofit organizations (companies) and did not closely connect to the innovation process as intermediaries.

Table 1 Amount of support from the Baross G. Program for innovation activities and services (in HUF1000)

\begin{tabular}{|l|r|r|r|r|r|}
\hline & \multicolumn{1}{|c|}{$\mathbf{2 0 0 6}$} & $\mathbf{2 0 0 7}$ & \multicolumn{1}{c|}{$\mathbf{2 0 0 8}$} & \multicolumn{1}{c|}{$\mathbf{2 0 0 9}$} & \multicolumn{1}{c|}{ Total } \\
\hline Central Hungary & 650424 & & 41211 & & 691635 \\
\hline Western Transdanubia & 832468 & & 175951 & & 1008419 \\
\hline Central Transdanubia & 1215193 & & 472548 & 94891 & 1782632 \\
\hline Southern Transdanubia & 795000 & 260000 & & 129669 & 1184669 \\
\hline Northern Great Plain & 1000000 & & 99997 & & 1099997 \\
\hline Northern Hungary & 735868 & 75725 & 374900 & 139414 & 1325907 \\
\hline Southern Great Plain & 727168 & 600000 & 71283 & & 1398451 \\
\hline Total & 5956121 & 935725 & 1235890 & 363974 & $\mathbf{8 4 9 1 7 1 0}$ \\
\hline
\end{tabular}

Source: own edition based on the data from the webpage of (NRDIO)

From the Baross Gábor Program, innovation intermediaries for their activities received near HUF 8,5 billion between 2006 and 2009. During these four years the most support was available in the Central Transdanubian Region and in the Southern Great Plain. The least support - except the central region - was allocated in the convergence region of Western Transdanubia. Comparing this with the number of organization which received the grants, we can see that in the Southern Great Plain the amount per organization was the highest and in the Northern Great Plain (except the central region) the lowest. The received amount per 
organizations, except the regions with the highest and lowest results, does not show significant differences in the regions - it is between 25 and 30 million HUF.

The above mentioned national level research also examined the regional distribution of the functioning Hungarian intermediaries and we can state that it is similar to the distribution showed in the above chart - the amount received from the Baross Program. Therefore, the amount and scale of the support directly influenced the number of established intermediaries. Stating - according to the literature listed in the introduction chapter - that innovation intermediaries have an effect on the innovation potential of the region, we can assume that the higher number of organization has a higher influence of the regional innovation potential. However, this assumption requires more and complex future statistical research, comparing our research results with the innovation data of the Hungarian Central Statistical Office $(\mathrm{KSH})$ - see Figure 1 - it is clear that in regions where the number of intermediaries are the highest, the rate of $R \& D$ expenditure is also apparently high. The increase in the innovation potential is influenced by several factors in a region, like local input-output networks, characteristics of companies in the region, innovation policy or financial support possibilities (Rechnitzer, 1993).

However, in Central Transdanubia, in Western Transdanubia and in the Northern Great Plain Region this correlation cannot be clearly confirmed.

Figure 1 Rate of R\&D expenditure (1000 inhabitants, HUF million)

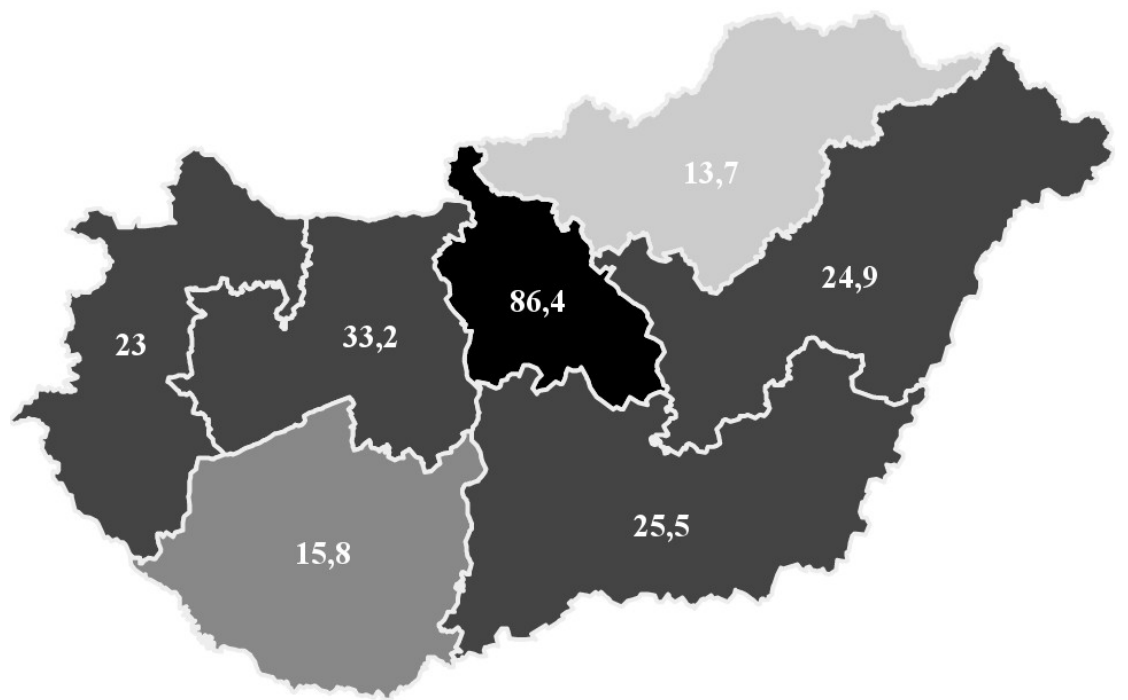

Resource: own edition by KSH4 data

\footnotetext{
${ }^{4}$ interactive map of the Hungarian Central Statistical Office: https://www.ksh.hu/interaktiv/terkepek/mo/kutfejl.html
} 
We examined the annual distribution of the Baross Program's grants too. The main part of the support was received by the organizations in the first year, in 2006 - this was more than $70 \%$ of the total amount. During the four years of the program, the support was gradually decreasing till in 2009 only organizations from three of the regions could apply for funding of 363 million HUF (see Table 1.).

Analysing the supports between 2007 and 2013 we examined further grants which promoted the activities, management and services of innovation intermediaries. In this period, mainly the European Union co-financed applications were available for the organizations. This amount exceeded 91bn HUF. The chart below (Figure 3) shows the received support from the calls listed in the Notes by regions.

Figure 3 Amounts of ÚMFT and ÚSZT grants by regions (HUF)

Resource: own edition

The results of analysing the grants of ÚMFT and ÚSZT are almost similar to the results in the Baross Program. Here the highest amounts for intermediaries (except the central region) were in Northern Hungary and in the Northern Great Plain Region. However, all Transdanubean Regions received less funding from these resources than other convergence regions. From the specific support (call TAMOP-4.2.1.) which aimed directly to develop the knowledge and technology transfer services of intermediaries -excluding the Central Hungarian Region (as it is not a convergence region) - Western Transdanubia and the Northern Great Plain Region received the highest amount. Thus, in these convergence regions 
the intermediaries could spend the most on the development of their services. The amount of the available EU funds for intermediaries also decreased gradually, however, the total annual sum was the highest in the second year. On the other hand, EU applications were projectbased and were aiming to support specific activities of intermediaries like the Baross Program's calls.

The total amount of the received grants by the innovation intermediaries from Baross and EU support - from 2006 to 2013 exceeded 120 bn HUF.

\section{Services of innovation intermediary organizations - Financial problems?}

Previously we referred to a research on organizations participating in the innovation process as intermediaries. In this national survey their services, target groups and effectiveness was investigated. Respondents had to indicate whether their organization deals with the given service and if they provide it to their target group or not. Based on their answers, we established a rank of top 10 services according to their frequency (see Table 2).

Table 1 Rank of services of the intermediaries

\begin{tabular}{|c|l|c|}
\hline \multicolumn{1}{|c|}{ Services } & \multicolumn{1}{|c|}{$\begin{array}{c}\text { Rate of organizations } \\
\text { offering the services (\%) }\end{array}$} \\
\hline $\mathbf{1}$ & establishment of cooperation with companies & $93,62 \%$ \\
\hline $\mathbf{2}$ & involvement of resources for innovation projects & $90,91 \%$ \\
\hline $\mathbf{3}$ & writing applications and tenders & $81,82 \%$ \\
\hline $\mathbf{4}$ & organizing TT+I education courses & $77,27 \%$ \\
\hline $\mathbf{5}$ & organizing other TT+I events & $74,42 \%$ \\
\hline $\mathbf{6}$ & innovation marketing & $74,42 \%$ \\
\hline $\mathbf{7}$ & searching for investors & $74,36 \%$ \\
\hline $\mathbf{8}$ & organizing spin-off education courses & $71,79 \%$ \\
\hline $\mathbf{9}$ & searching for new R\&D results K+F & $71,11 \%$ \\
\hline $\mathbf{1 0}$ & establishment of international cooperation & $65,79 \%$ \\
\hline
\end{tabular}

Resource: own edition

According to Table 2 most of the intermediaries (93\%) aim to establish cooperation with companies. The second and the third service in the rank are the involvement of resources and the writing of application which are closely connected to each other. More than 90 and $80 \%$ of the intermediaries offer these services. Among the top 10 services, on the 7th place we can find another service which is also connected to financing (services connected to financing are written in bold). This indicates that financing and involving resources are extremely important - more important than other services - for intermediaries. 
The survey focusing on innovation intermediaries also examined the target group - as control groups - of these organizations. All the researches confirmed that one of the biggest barriers which hinder innovation in the target groups is the lack of resources (e.g. more than $80 \%$ of the respondents mentioned it in the regional research). These answers inevitably justify the findings of the research by Grosz-Csizmadia-Szépvölgyi (2004). In their article they emphasized that intermediaries struggle with financial problems and this directly affects their operational effectiveness. Reciprocally, management and operational problems of these organizations can negatively influence the innovation potential of the region.

\section{CONCLUSION}

We cannot state that there were not enough resources available for the organizations participating in the innovation process as intermediaries. In Hungary, not only EU grants but national supports were also opened for the development of the innovation services of these organizations. Intermediaries received more than 120 bn HUF grants from the Baross Gábor Program and also from the EU funds. Spatial distribution of the support of the Baross fund between the convergence regions did not differed significantly; however, EU co-financed funds were mainly focused in the eastern part of Hungary.

According to the literature - see Lundvall (2002), Nagaoka et al. (2009), Arocena-Sutz (2002), Filippetti-Archibugia (2011), Guana-Chen (2012), Flanagana et al. (2011) - for the development of the innovation potential, it is essential to support and motivate the activities of the organization which participate in the innovation process. This support needs to be stable and annually consistent. Only this can ensure the continuous and sustainable functioning and stable services of the innovation in intermediary organizations. According to the research results examining the resources described above, we can state that the support of Hungarian intermediary organizations is not stable. Annual allocation of grants is changing - there were more available grants in the beginning and only a few at the end of the periods. Besides, resources also have a different intensity according to regions. This instability directly influences the functioning and services of the organizations and it can indirectly contribute to the decrease in the effectiveness of the Hungarian innovation process as well.

Project based and specific funding (promoting specific activities) also causes problems for intermediaries as it cannot ensure stable management. Most of the services of innovation intermediaries are not profit-oriented and cannot directly result in incomes. Therefore unpredictable and project-based supports result in financial problems for them. Intermediaries, however, can have difficulties if they try to involve investors or other 
resources for the maintenance of their services due to the low level of trust in Hungary (see Inzelt, 1998, 2003 describing the role of trust in the Hungarian innovation system).

For the intermediary organizations searching for and the involvement of resources is significant and this exacting work takes their attention away from other, more important services supporting the innovation process.

More effective distribution of the grants, stable financing and resources aiming directly the operation of the organizations can improve and solve financial problems and this way it can increase the effectiveness of the intermediary organizations.

The results of our research can be supplemented with further complex researches focusing on the relations between the number of organizations and its influence of the innovation potential. Hungarian innovation policy and regional policy have an influence on the innovation capacities of the regions which should also be examined in details in a future survey.

And by increasing the effectiveness of the services Hungarian intermediaries provide, the innovation potential of regions and actors participating in the innovation process can also improve.

\section{NOTES}

The calls of the Baross Gábor Program differed by regions. We examined the following calls:

- Courses for the human side of innovation (EA_KEPZ_07)

- Research and development and innovation program (EA_KFI_07)

- Research and development asset acquisition (KM_ESZK_07, DA_ESZK_07)

- Supporting the acquisition of R+D+I services (Central Transdanubian Region)

- Product and technology and service innovation (Southern Transdanubian Region)

- $\quad$ Spin off (ND_INRG2_07)

- Knowledge and technology transfer (Southern Transdanubian Region)

We examined the following ÚMFT calls which were available for innovation intermediaries:

- Supporting knowledge and technology transfer services and the development of higher educational institutes' research facilities (TÁMOP 4.2.1-09/1)

- Development of assets and facilities promoting the knowledge utilization and knowledge transfer (TÁMOP 4.2.1-08/1)

- Promotion and dissemination of scientific results (TÁMOP 4.2.3-08/1, TÁMOP 4.2.3-12/1/KONV)

- Increasing the quality of higher education through the development of research-developmentinnovation-education (TÁMOP 4.2.1/B-09/1/KONV, TÁMOP 4.2.1.B-10/2/KONV)

The following ÚSZT calls (2011-2013) were examined:

- Development of innovation and technology parks and development centres (GOP 1.2.1-12/B)

- Regional Operative Programs:

- Support for the business infrastructure and investment area - for industrial parks and incubators (ROP 1.3.1/ABC-11)

- Support for the cooperation with companies and clusters (ROP 1.1.1/A-11)

- Promotion and dissemination of scientific results (TÁMOP 4.2.3-12/1/KONV)

- Development of the regional, social and economic role of higher education (TÁMOP 4.1.1.F-13/1) 


\section{REFERENCES}

Afuah, A. (2003). Innovation management, Strategies, Implementation and profits, 2nd ed., Oxford University Press, New York, USA

Arocena, R., Sutz, J. (2002). Innovation Systems and Developing Countries, DRUID Working Paper No 02-05, downloaded: http://www3.druid.dk/wp/20020005.pdf, 2013.05.14., 10:10

Barta, Gy. (Buzás-Lengyel szerk.) (2002). Tudományos parkok: intézményesült tudásközösségek a térségfejlesztésben, Ipari parkok fejlődési lehetőségei: regionális gazdaságfejlesztés, innovációs folyamatok és klaszterek. [Scientific Parks: Institutionalized Knowledge Communities in Regional Development. Development Possibilities of Industrial Parks: Regiona Economic Development, Innovation Processes and Clusters], JETEPress, Szeged, 109-124.p.

Buzás, N. (2007). Innovációmenedzsment a gyakorlatban, [Innovation management in practice], Akadémiai Kiadó, Budapest, 360 p.

Csizmadia, Z., Grosz, A. (2011). Innovációs és együttmüködés, A kapcsolathálózatok innovációra gyakorolt hatása, [Innovation and cooperation, Effect of cooperation networks on the innnovation], MTA Regionális Kutatások Központja, Pécs-Györ

Dániel, Z.A., Molnár, T. (2013). KKV-k fejlesztési forrásainak hatásvizsgálata, [Effectiveness research of development grants for SMEs], in A felfedező tudomány (szerk Beszteri B.), ISBN: 978-963-508-632-0, letöltve: http://kgk.sze.hu/a-felfedezo-tudomany, 2015. május 30., $15: 20$

Dőry, T. (1996). A kutatás-fejlesztés egyes jellemzőinek területi szerkezete, [Spatial framework of several characteristics of research and develpment], Tér és Társadalom, 1996/2-3., 157168. p.

Fagerberg, J., Mowery, D.C., Nelson, R.R. (2005). The Oxford Handbook of Innovaton, Oxford University Press, US, 2005. 656 p.

Fagerberg, J. (1994). Technology and International Differences in Growth Rates. Journal of Economic Literature, Volume 32(3), 1147-1175. o., letöltés dátuma: 2014.03.13. http://www.deu.edu.tr/userweb/sedef.akgungor/dosyalar/fagerberg.pdf.

Filippetti, A., Archibugia, D. (2011). Innovation in times of crisis: National Systems of Innovation, structure, and demand. Research Policy, Volume 40, Issue 2, 179-192. o.

Flanagana, K., Uyarraa, E., Laranjab, M. (2011). Reconceptualising the 'policy mix' for innovation. Research Policy, Volume 40, Issue 5, 702-713. o.

Freeman, C. (1987), Technology and Economic Performance: Lessons from Japan, Pinter, London, $155 \mathrm{p}$.

Freeman, C. (1995), "The National System of Innovation in Historical Perspective", Cambridge Journal of Economics, No. 19, pp. 5-24

Grosz, A.-Csizmadia, Z.-Szépvölgyi Á.: A regionális innovációs rendszer kínálati oldala a Közép-Dunántúlon, [Supply side of regional innovation system in Central-Transdanubea], Tér és Társadalom, 2004/3., 111-149. p.

Guana, J., Chen, K. (2012). Modeling the relative efficiency of national innovation systems. Research Policy, Volume 41, Issue 1, 102-115. o.

Horváth, Gy. (1998) Európai regionális politika. Dialóg Campus, Budapest-Pécs.

Howlett, R. J. (ed.) (2011). Innovation through Knowledge Transfer 2010. Springer-Verlag, Berlin-Heidelberg. ISBN 978-3-642-20507-1.

Inzelt, A., Szerb, L. (2003). Az innovációs aktivitás vizsgálata ökonometriai módszerekkel, [Examining innovation activity with econometric methods], Közgazdasági Szemle, Mühely, L. évf., 2003. november, 1002-1021. p.

Inzelt, A. (1998). Bevezetés az innovációmenedzsmentbe, [Introduction to innovation management], Müszaki Könyvkiadó - Magyar Minőség Társaság, Budapest 
Jain, R.K., Triandis, H. C., Weick, C. W. (2010). Managing Research, Development and Innovation: Managing the Unmanageable, John Wiley \& Sons, Inc

Landes, D. (1998). The Wealth and Poverty of Nations, United States, Boston, ISBN 0393318885, W.W. Norton \& Company Inc., 658 p.

Lengyel I., Rechnitzer, J. (2004, 2009) Regionális gazdaságtan. Dialóg Campus Kiadó, Budapest-Pécs.

Lengyel, B., Leydesdorff, L. (2008) A magyar gazdaság tudásalapú szerveződésének mérése: az innovációs rendszerek szinergiáinak térbelisége. [Measuring the knowledge based structure of the Hungarian economy: spatial dimension of innovation systems' synergy] Közgazdasági Szemle, LV, Június, pp. 522-547.

Lóránd, B. (2008). Regionális fejlesztések értékelésének problematikája az Európai Unióban, Kérdőjelek a régiók gazdasági fejlödésében [Problems of the evaluation of regional development in the European Union, Question marks in the economic development of the regions] (Lengyel - Lukovics), JATEPress, Szeged, pp. 153-166.

Lundvall, B- $\AA$ (2002). The University in the Learning Economy, letöltve: http://www3.druid.dk/wp/20060006.pdf, 2014.04.27., 10:10

Lundvall, B.-Á. (ed.) (1995). National Systems of Innovation. Towards a Theory of Innovation and Interactive Learning, Pinter Publishers, London, 1995., 342 p.

Mezei, K. (2004). Integrált regionális fejlesztés-finanszírozási modell a Nyugat-Dunántúlon, [Integrated regional development financing model in Western-Transdanubea], Tér és Társadalom, 18. évf. 2004/4. 51-68. p.

Molnár, I. (2004). Az Amerikai Egyesült Államok innovációs rendszerének jogi és intézményi vonásai, [Legal and institutional side of the innovation system of the USA], Marketing menedzsment, XXXVIII. Évfolyam, 2004/5. szám, 65-75. p.

Nagaoka, S. - Kondo, M. - Flamm, K. - Wessner, C. (2009.). 21 st Century Innovation System for Japan and the United States, Comparative Innovation Policy, The National Academic Press, Washington, D.C.

Nelson, R.R (1993). National Innovation Systems, A comparative analysis, ISBN: 9780195076172, New York: Oxford University Press, 560 p.

Perger, É. (2010). Az EU kohéziós politika kormányzati irányításának magyar sajátosságai, [Hungarian peculiarities of the governing direction of EU cohesion policy], Tér és Társadalom, 24. évf. 2010/1. 119-136. p.

Rechnitzer, J. (1993). Szétszakadás vagy felzárkózás. A térszerkezet alakító innovációk. MTA Regionális Kutatások Központja, Győr.

Stamm, B. (2003). Managing Innovation, Design and Creativity, London Business School

Szépvölgyi, Á. (2006). A tudásközvetítés és -felhasználás helyi hálózatai a Közép-Dunántúlon, [Local networks of knowledge transfer and usage in Central-Transdanubea], Tér és Társadalom, 2006/4., 145-160. p.

Vekinis, G. (2007). Best Practice for Technology Transfer, A Best Practice Manual for Successful Transfer of Technologies, Know-how and Knowledge to Industry, Commerce and Society, 2007. június, $80 \mathrm{p}$.

Vekinis, G. (2014). Technology Transfer in practice: from Invention to Innovation - a step-bystep guide for Researchers and Inventors, ISBN: 978-960-93-5855-2 